Вісник Львівського університету. Серія філос.-політолог. студї. 2020. Випуск 31, с. 105-111

Visnuk of the Lviv University. Series Philos.-Political Studies. Issue 31, p. 105-111

UDC 327

DOI https://doi.org/10.30970/PPS.2020.31.14

\title{
CULTURAL AND POLITICAL ASPECT AS A FOUNDATION AND A KEY LINK IN THE EXPANDING RELATIONS BETWEEN AZERBAIJAN AND GREECE
}

\author{
Ilyas Huseynov \\ Baku Slavic University, \\ Department of International Relations \\ S. Rustam str., 33, AZ1072, Baku, Azerbaijan
}

\begin{abstract}
After Azerbaijan gained independence, relations with Greece began to develop successfully. Greece is one of the first countries to recognize the independence of Azerbaijan. This article examines the dynamics of humanitarian ties between Azerbaijan and Greece. Cultural relations always play a crucial role in the development of bilateral relations. The expansion of cultural ties between Greece and Azerbaijan has a positive impact on other areas as well. Humanitarian relations play an important role in bilateral relations. The paper also outlines the main directions of humanitarian relations between Azerbaijan and Greece. Special attention is paid to the events held in Greece with the aim of promoting the culture and rich heritage of Azerbaijan. It is noted that various concerts, cultural days, book exhibitions, and country presentations help bring peoples and cultures closer together. The article provides a possible classification of the ways of cooperation in the cultural and political context between Azerbaijan and Greece. The influence of the signed agreements and adopted programs between the Government of the Republic of Azerbaijan and the Government of the Hellenic Republic, which formed the main legal basis of bilateral humanitarian relations, is studied. The article discusses the goals of cultural policy and diplomacy between Azerbaijan and Greece. In modern international relations, cultural diplomacy plays an important role in bringing countries closer together. From this point of view, the initiatives undertaken in the cultural and political aspect help to bring closer not only Greece and Azerbaijan, but also the Caucasus region with the Balkans. At the same time, the work pays special attention to the analysis of the activities of the Heydar Aliyev Foundation, which held a number of events in Greece aimed at rapprochement of relations between Azerbaijan and Greece. The article also outlines the main features of the state policy of Azerbaijan in the field of cultural activities in the Greek direction. The article analyzes the processes of transformation of humanitarian ties between Azerbaijan and Greece. The scientific work analyzes the general conceptual approaches of cultural ties, which contribute to the expansion of relations, both at the bilateral and multilateral levels.

Key words: cultural and political aspect, Greece, cultural relations, humanitarian relations, culture, cultural diplomacy, sociocultural activity, intercultural communication.
\end{abstract}

Relevance of research and formulation of scientific problem. After gaining independence with the collapse of the USSR, Azerbaijan began to establish bilateral relations with a number of states. Humanitarian relations always have a positive impact on political and economic relations. From this point of view, the study of humanitarian relations between Azerbaijan and Greece is of great relevance.

Research analysis. This problem has not been studied either in Azerbaijan or Greece. Therefore, most of the materials we collected were obtained from periodicals. At the same time, the article used the works of R. Mustafaev and A. Alifli.

The aim of the article. The main purpose of the article is to consider the cultural aspects that significantly affect the development of bilateral relations between Azerbaijan and Greece.

(C) I. Huseynov, 2020 
Presentation of the main material of the research. In the modern period, political, economic and humanitarian relations are successfully developing between Azerbaijan and Greece. Greece is considered the cradle of European culture and Western civilization in general. The signing of a number of agreements and the adoption of programs that form the legal and regulatory framework for cooperation in the humanitarian sphere increase the incentive value for expanding bilateral relations. On April 11, 1997, an Agreement was signed between the Government of the Republic of Azerbaijan and the Government of the Hellenic Republic on cooperation in the field of education, culture and science. On April 11, 2003, the Program of cooperation in science, education and culture between the Government of the Republic of Azerbaijan and the Government of the Hellenic Republic for 2002-2005 was adopted. On April 5, 2011, the Government of the Republic of Azerbaijan and the Government of the Hellenic Republic adopted the Program of cooperation in the field of science, education and culture for 2011-2012-2013. Thanks to the above-mentioned legal documents, the basis for cooperation in the fields of education, science and culture was laid in bilateral relations.

Important steps are being taken today to develop cultural ties between Azerbaijan and Greece. Cooperation between Azerbaijan and Greece in the field of culture is considered one of the main elements of bilateral relations, and recently cooperation in this area has significantly intensified. The visits of the heads of state contributed to the further development of relations between Azerbaijan and Greece. On June 22, 2004, during an official visit to Azerbaijan, President of the Hellenic Republic Konstantinos Stephanopoulos took part in a concert of Azerbaijani and Greek music performed by the State Symphony Orchestra of Azerbaijan named after Uzeyir Hajibeyov at the Azerbaijan State Philharmonic named after Muslim Magomayev. At the concert, the well-known musical group of the Republic under the direction of the people's artist of Azerbaijan Rauf Abdullayev and the Greek conductor Giorgos Tsangaris skillfully performed "Azerbaijan Capriccio" - a masterpiece by Fikret Amirov, fragments from the ballet Giorgos Tsangaris, "Prometheus" and Kara Garayev "The Path of Thunder", Nikos Skalkottas symphony "Two dances". The famous Greek composer and conductor Giorgos Tsangaris expressed deep gratitude to the musicians of the Azerbaijan State Symphony Orchestra for their excellent performance and highly appreciated their art. He emphasized that it is a great honor for him to perform in front of the presidents of Azerbaijan and Greece, and presented Rauf Abdullayev with a special medal depicting the outstanding Greek conductor Mitropoulos [12].

On February 16, 2009, President of the Republic of Azerbaijan Ilham Aliyev visited the National Archaeological Museum in Athens during his visit to Greece. The head of state was informed that the museum displays exhibits reflecting the most ancient periods of the history of Greece, the museum is one of the most interesting places for tourists coming to Athens, and creates for them a clear idea of the ancient history of Greece, the life and occupations of people.

In October 2010, a concert dedicated to the 125th anniversary of the outstanding Azerbaijani composer Uzeyir Hajibeyov was held in the capital of Greece Athens. Before this concert, clips of Azerbaijani performers were shown on Greek television, and the waltz of Gara Garaev was broadcast on the radio. The concert was organized at the Athens State Philharmonic, which is considered the second concert hall in the world after the Berlin Philharmonic. The concert was conducted by the National Symphony Orchestra under the baton of Azad Aliyev. At the anniversary event of U. Hajibeyov, the audience greeted the performance of pianist Farhad Badalbeyli, soloists Gulnaz Ismayilova, Sabina Asadova and baritone Javid Samedov. Along with Uzeyir Hajibeyli, the program featured works by Gara Garayev, Fikret Amirov, Niyazi and Farhad Badalbeyli [13]. 
On October 15, 2011, the Azerbaijan State Philharmonic named after Muslim Magomayev hosted a concert of the Azerbaijan State Symphony Orchestra named after Uzeyir Hajibeyov under the direction of the Greek conductor Byron Fidetzis. The initiator of the concert, organized by the Greek Embassy in Baku and the Azerbaijan State Philharmonic, is the National Gas Corporation of Greece DEPA. The concert included an overture from the opera "Prometheus" by Ludwig van Beethoven, as well as for the first time in Baku a concert for clarinet and orchestra by Carl Nielsen, "Five Greek Dances" by Nikos Skalkottas and Symphony No.1 "Levendia" by Manolis Kalomiris [2].

The Azerbaijani Embassy in Greece organized 8 concerts of symphonic, jazz, classical and folk music in 2010-2014 to promote Azerbaijani culture and music, and these cultural events played an important role in strengthening bilateral relations. Concerts were organized in various Greek cities - Athens, Thessaloniki and Xanthi, as well as on the island of Tinos. In October 2011, the Azerbaijani orchestra performed the music of the popular Greek composer Manolis Kalomiris in Baku. [6, p. 11].

The Heydar Aliyev Foundation provides invaluable services in the development and popularization of Azerbaijani national culture in the world. The foundation, which has a wide reputation in the international arena, is expanding the scope of its activities and holding events to promote Azerbaijani culture in different countries of the world. On June 6, 2014, with the support of the Azerbaijani Embassy in Greece at the Athens cultural complex "Megaro Mousikis", the Azerbaijan State Chamber Orchestra named after Gara Garayev performed an extensive concert program. It should be noted that the event was held with broad information support of the first event of the "Azerbaijan music season", a website www.azerbaijani-culture.gr was created in a special database, the purpose of which is to cover a series of events in Greece. Then the Azerbaijani musicians performed a concert program under the direction of people's artist Teymur Goychaev. Along with the works of great Azerbaijani composers - Uzeyir Hajibeyov, Fikret Amirov, Gara Garayev, Jahangir Jahangirov, Niyazi and Vagif Mustafazadeh, the works of world famous musicians such as Astor Piazzolla, Pablo de Sarasate, Ernesto De Curtis were performed at the classical music concert. The composition of the well-known tar performer Shahriyar Imanov, consisting of a synthesis of Azerbaijani mugams and the beloved dance of the Greek people "Sirtaki", was greeted by the audience with thunderous applause. Khanende Arzu Aliyeva, Maftun Safarli performed mugams, Azer Rzayev (tenor) performed works of Azerbaijani and European composers. Accompanied by the orchestra, Murad Adigozalzade (piano), Elvin Ganiev (violin), Nijat Masimov (Balaban), Elchin Shirinov (piano) and Shahriyar Imanov (tar) performed works of both national and foreign music with high technique and skill. After the concert, the guests got acquainted with various publications published by the Heydar Aliyev Foundation in recent years. Among the publications on the ancient and rich Azerbaijani culture are books dedicated to the Azerbaijan National Art Museum, musical instruments, manuscripts, and various types of folk art, CDs with pop music, jazz, mugham and classical music, as well as works of great thinkers Nizami Ganjavi and Mahsati Ganjavi were introduced to the participants [1].

On June 15,2014 , within the framework of a visit to Greece, President of the Republic of Azerbaijan Ilham Aliyev and his wife Mehriban Aliyeva visited the Athens Acropolis. This sacred rock, which means "Upper City" and is considered a symbol of Athens, combines ancient civilization and modernity. Among the important factors that increase the importance of the Acropolis, of course, are the temples of the Pantheon, Athens and the Erechtheion, which are rare gems of world architecture and most of these historical monuments have survived to present day. 


\section{Days of Azerbaijan Culture in Greece}

On September 27-28, 2014, with the support of the Heydar Aliyev Foundation, the Days of Azerbaijani Culture were held in Athens. It was organized by the Heydar Aliyev Foundation, the Azerbaijani Embassy in Greece and the Marianna Vardinoyannis Greek Foundation at the Herodion Theatre, one of the oldest venues in Athens. The State Symphony Orchestra named after Uzeyir Hajibeyli conducted by the honored art worker Fakhreddin Kerimov and the State Dance Ensemble performed for the Athenian audience. Mugham was also performed at the concert, which is an important part of the Azerbaijani professional musical culture and has ancient roots in the cultural traditions and history of our people. At the concert, held within the framework of the Days of Azerbaijani Culture, the audience was presented with immortal works of art $[10$, p. 8$]$. The audience enjoyed a unique performance that combined the long standing dance traditions of Azerbaijan with the music of the State Symphony Orchestra, creating a balance between classical and modern, traditional and cosmopolitan sound [7]. The concert showed that our country is equally respectful both to national values and to modern trends. The audience felt this unity in interesting interpretations of national music.

\section{Presentation of the first European Games in Athens}

On September 28, 2014, the Heydar Aliyev Foundation held a presentation of the first European Games, which were successfully held in 2015, at the Acropolis Museum in Athens. The ceremony was attended by First Vice President of Azerbaijan, President of the Heydar Aliyev Foundation Mehriban Aliyeva, Speaker of the Greek Parliament, Deputy Prime Minister, Minister of Administrative Reforms, Minister of Tourism, deputies, and representatives of the Greek sports community. On March 16, 2017, First Vice-President of the Republic of Azerbaijan Mehriban Aliyeva met with UNESCO Goodwill Ambassador, President of the Association of Friends of Children with Cancer "ELPIDA" and "Marianna V. Vardinoyannis Foundation" Marianna Vardinoyannis. At the meeting, it was noted that the Azerbaijani-Greek cooperation is developing in the social sphere, education and healthcare. The UNESCO Goodwill Ambassador remembered with pleasure the visit of Mehriban Aliyeva to Greece in 2014. She thanked the First Vice President for supporting ELPIDA's activities. Marianna Vardinoyannis stressed the need to exchange experience in this area and noted the possibility of further expanding relations. Mehriban Aliyeva noted that the concert organized by the Heydar Aliyev Foundation in Greece aroused great interest, adding that it played an important role in popularizing the culture of Azerbaijan in Greece [3].

On March 29, 2018, in Baku at the International Mugham Center, a concert was held by the artistic director of the Athens Opera House (Greece), performer on the ancient stringed instrument lyre, composer Nikos Xantoulis. The concert program was timed to coincide with the Independence Day of Greece and was organized with the support of the Greek Embassy in Azerbaijan. At the evening, accompanied by the Chamber Orchestra "Baku Virtuosi", Nikos Xantoulis performed on the lyre works by classical and modern Azerbaijani and foreign authors - Gara Garayev, Christoph Gluck, Stefano Muscaritolo, George Handel and others. The conductor of the orchestra is the honored artist of Azerbaijan, laureate of international competitions Eyyub Guliyev. The honored artist of Azerbaijan Ilham Nazarov (countertenor) and Rovshan Amrahov (violin) also took part in the concert. The magnificent performance was accompanied by an ovations from the audience, and the culmination of the evening was the Azerbaijani folk song "Sari gelin" [11].

Activities of the Modern Greek Language and Culture Center at Baku Slavic University

In relations between Athens and Baku, the special place of science and education should be separately noted.

The Modern Greek Language and Culture Center, which opened on June 22, 2004 at the Baku Slavic University with the participation of the President of the Hellenic 
Republic Constantinos Stephanopoulos, also promotes bilateral relations through its activities. The center was established with the support of the Greek government and the Greek Embassy in Azerbaijan. The center has a library with materials on Greek history, culture, literature, modern Azerbaijani-Greek relations, as well as classrooms equipped with technical facilities. About 50 students study at the Modern Greek Language and Culture Center at the Baku Slavic University [8]. The services of the center are used by university students specializing in Greece, other European countries, specialists interested in economic, cultural, humanitarian ties between Azerbaijan and Greece. It hosts cultural events, meetings with statesmen, scientists and cultural figures of Greece, thematic seminars, lectures. The center has a Greek language and culture circle [5].

Officials of the Hellenic Republic who are on a visit to Azerbaijan visit the Slavic University, noting the importance of the functioning of the Greek Center, calling it a bridge connecting two states with a rich cultural heritage. One of the important priorities of the cultural center is the translation of fiction, both prose and poetry, from the modern Greek language into Azerbaijani, as well as from the Azerbaijani language into the modern Greek language. 2013 was declared by the international organization UNESCO as the year of the great Greek poet Konstantinos Kavafis. The translation of Kavafis's poetry into Azerbaijani is the first step to acquaint the Azerbaijani reader with modern Greek literature, in particular with poetry, which displays the invisible web of the poet's philosophical views against the background of the Hellenistic era, intertwined with the modern West.

In connection with the 130th anniversary of the birth of Huseyn Javid, a prominent representative and one of the founders of progressive romanticism in Azerbaijan, the famous drama "Sheida" was translated into Greek. Another important work in the translation activity of the Modern Greek Language and Culture Center is the translation from Azerbaijani into Greek of a literary essay by the great Azerbaijani poet Mahsati Ganjavi. The book was published in accordance with the order of the President of Azerbaijan Ilham Aliyev "On holding the 900th anniversary of Mahsati Ganjavi” dated January 16, 2013 [9, p. 79-80].

Conclusions. In general, cultural and political cooperation between Azerbaijan and Greece should be considered as part of a broader humanitarian interaction. Therefore, we must strive to ensure that active, substantive cooperation covers all its areas, not only culture. We are talking about cooperation in the field of science and education, youth and sports exchanges, interfaith dialogue and tourism. Through such contacts, familiarization with the history and culture of the country, its internal life, customs and tradition takes place. Therefore, it is necessary to maintain these contacts in every possible way, considering them as the most important mechanism for rapprochement between Greece and Azerbaijan and the peoples of these countries.

\section{References:}

1. A concert by the Azerbaijan State Chamber Orchestra named after Gara Garayev takes place in Greece with the support of the Heydar Aliyev Foundation / Heydar Aliyev Foundation. 06.06.2014. URL: https://heydar-aliyev-foundation.org/en/content/view/59/3344/A-concertby-the-Azerbaijan-State-Chamber-Orchestra-named-after-Gara-Garayev-takes-place-inGreece-with-the-support-of-the-Heydar-Aliyev-Foundation- (Last accessed: 18.06.2020).

2. Azerbaijan State Philharmonic Hall hosts concert of country`s Symphony Orchestra. Azerbaijan State News Agency. 15.10.2011. URL: https://azertag.az/en/xeber/Azerbaijan State_Philharmonic_Hall_hosts_concert_of_countrys_Symphony_Orchestra-613043 (Last accessed: $18.06 .202 \overline{0}$ ).

3. First Vice-President Mehriban Aliyeva meets with UNESCO Goodwill Ambassador Marianna Vardinoyannis. President.az. 16.03.2017. URL: https://en.president.az/articles/23614 (Last accessed:18.06.2020). 
4. Ismayilova. L. Famous Greek musician performs Azerbaijani folk song. Azernews.az. 02.04.2018. URL:https://www.azernews.az/culture/129610.html (Last accessed: 18.06.2020).

5. Modern Greek Language and Cultural Center / Baku Slavic University. URL: https://bsu-uni.edu.az/en/centers/8/ (Last accessed: 18.06.2020).

6. Mustafayev R. Azerbaijani-Hellenic Relations in 2013: Opening New Horizons for Bilateral Cooperation. 10th issue of Middle East Mediterranean Report focuses on Greek-Azerbaijani relations / Athens: ELIAMEP (Hellenic Foundation for European and Foreign Policy). 4/2 September-December 2013, pp. 5-11.

7. Orujova, N. Athens hosts concert as part of Azerbaijani Culture Days. Azernews.az. 29.09.2014. URL: https://www.azernews.az/nation/71276.html (Last accessed: 18.06.2020).

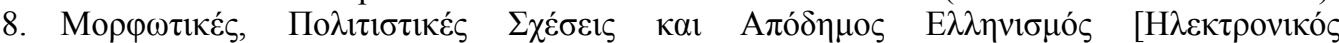

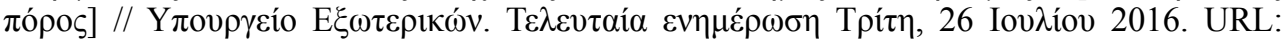
https://www.mfa.gr/dimereis-sheseis-tis-ellados/azerbaijan/morphotikes-politistikessxeseis-kai-apodimos-ellinismos.html (Last accessed: 18.06.2020).

9. Алифли, А. Сотрудничество Азербайджана и Греции в области культуры. Научная работа. Ежемесячный международный научный журнал по гуманитарным наукам. Баку, 2019, № 2 (3). С. 78-80.

10. Асадова И. Дни культуры Азербайджана в Греции. Газета Эхо. 30.09.2014.

11. Иманов, В. Никос Ксантулис поразил игрой на древней лире и исполнением «Сары гялин». Trend.az. 30.03.2018. URL: https://www.trend.az/life/culture/2879625.html (Last accessed: 18.06 .2020$)$

12. Президенты Азербайджана и Греции присутствовали на концерте в государственной филармонии. Azerbaijan State News Agency. 22.06.2004. URL: https://azertag.az/ ru/xeber/PREZIDENTY AZERBAIDZHANA I GRECII PRISUTSTVOVALI NA KONCERTE V GOSUDĀRSTVENNOI FILARM̄ŌNII-63092̄7 (Last accessed: 18.06.2020).

13. Таривердиева Э. Азербайджанская музыка прозвучала в Греции. Trend.az. 06.10.2010. URL: https://www.trend.az/azerbaijan/society/1762155.html (Last accessed: 18.06.2020).

\title{
КУЛЬТУРНО-ПОЛІТИЧНИЙ АСПЕКТ ЯК ФУНДАМЕНТ І КЛЮЧОВА ЛАНКА В РОЗШИРЕННІ ВІДНОСИН МІЖ АЗЕРБАЙДЖАНОМ І ГРЕЦІЄЮ
}

\author{
Ільяс Гусейнов \\ Бакинський слов'янський університет, \\ кафедра міжнародних відносин \\ вул. С. Рустама, 33, AZ1072, м. Баку, Азербайджан
}

\begin{abstract}
Після здобуття незалежності Азербайджану відносини з Грецією успішно стали розвиватися. Греція - одна $з$ перших країн, яка визнала незалежність Азербайджану. У цій статті розглянута динаміка гуманітарних зв'язків між Азербайджаном і Грецією. Культурні відносини завжди відіграють вирішальну роль у розвитку двосторонніх відносин. Розширення культурних зв'язків між Грецією і Азербайджаном чинить позитивний вплив і на інші сфери. Гуманітарні відносини відіграють важливу роль у двосторонніх відносинах. У роботі також позначені головні напрями гуманітарних відносин між Азербайджаном і Грецією. Особлива увага приділяється проведеним заходам у Греції з метою пропаганди культури і багатої спадщини Азербайджану. Відзначається, що різні концерти, дні культури, книжкові виставки, презентації країн допомагають зблизити народи і культури. У статті наводиться можлива класифікація способів співпраці в культурно-політичному контексті між Азербайджаном і Грецією. Досліджується вплив підписаних угод і прийнятих програм між Урядом Азербайджанської Республіки і Урядом Грецької Республіки, які становили основну правову базу двосторонніх гуманітарних відносин. У статті розглядаються цілі проведення політики
\end{abstract}


Вісник Львівського університету. Серія філос.-політолог. студї. 2020. Випуск 31

і дипломатії в сфері культури між Азербайджаном і Грецією. У сучасних міжнародних відносинах культурна дипломатія грає важливу роль у зближенні країн. 3 цієї точки зору ініціативи, запроваджені в культурно-політичному аспекті, допомагають зблизити не тільки Грецію і Азербайджан, а й Кавказький регіон з Балканами. При цьому в роботі особлива увага приділяється аналізу діяльності Фонду Гейдара Алієва, що провів у Греції низку заходів, спрямованих на зближення відносин між Азербайджаном і Грецією. У статті також позначені головні напрями державної політики Азербайджану в сфері культурної діяльності в грецькому напрямі. У статті проаналізовано процеси трансформації гуманітарних зв'язків між Азербайджаном і Грецією. У науковій роботі проаналізовані загальні концептуальні підходи культурних зв’язків, які сприяють розширенню відносин як на двосторонньому, так і на багатосторонньому рівні.

Ключові слова: культурно-політичний аспект, Греція, відносини в сфері культури, гуманітарні відносини, культура, культурна дипломатія, соціокультурна діяльність, міжкультурна комунікація. 